\title{
Trophic impact of long-lived species indicated by population dynamics in the short-lived hydrozoan Eudendrium racemosum
}

\author{
Sergio Rossi ${ }^{1, *}$, Lorenzo Bramanti ${ }^{2}$, Elisabetta Broglio² ${ }^{2}$ Josep María Gili ${ }^{2}$ \\ ${ }^{1}$ Institut de Ciència i Tecnologia Ambientals, Universitat Autònoma de Barcelona (UAB), Campus Cn UAB s/n, \\ Cerdanyola Del Vallès 08193, Spain \\ ${ }^{2}$ Instituto Ciencias del Mar (CSIC), Passeig Marítim de la Barceloneta 39-47, Barcelona 08003, Spain
}

\begin{abstract}
Population dynamics, morphology, density, lipid contents and prey capture rates were studied in a patchy population of the tree-like passive suspension feeder Eudendrium racemosum (Cnidaria: Hydrozoa) during seasonal cycles. Density and size of colonies oscillated due to intraspecific competition (following the self-thinning rule) and predation (nudibranchs) showing size distributions in which alternatively large- and small-sized colonies were more abundant. Increase in the trophic impact on the water column was correlated with colony size $\left(30.7 \mathrm{mg} \mathrm{C} \mathrm{m}{ }^{-2}\right.$ $\mathrm{d}^{-1}$ in late spring-early summer compared with $10.2 \mathrm{mg} \mathrm{C} \mathrm{m}^{-2} \mathrm{~d}^{-1}$ in the rest of the year). Lipid accumulation in the hydrocauli followed the same trend, being higher during the reproductive period (140 $\mathrm{\mu g}$ lipids $\mathrm{mg}^{-1}$ organic matter [OM]) compared with the rest of the year $(70 \mu \mathrm{g}$ lipids $\left.\mathrm{mg}^{-1} \mathrm{OM}\right)$. The short time cyclic variations reproduce, in a short time scale, the variations studied in other benthic suspension feeders, suggesting E. racemosum as a model organism to better understand the importance of large colonies in long-lived species in benthic-pelagic coupling processes. The accordance with the self-thinning rule found for this animal species strengthens the animal forest concept (a 3-dimensional live structure composed mainly by heterotrophic organisms such as gorgonians, bryozoans, and sponges), confirming the validity of the utilization, by marine ecologists, of the conceptual tools developed for terrestrial forest sciences. It is suggested that the impact of mature populations on benthic-pelagic coupling and biogeochemical cycles, simulated for long-lived species, could be validated by studying fast-growing species, in order to understand the importance of the preservation of complex structures and long-lived ecoengineering organisms in benthic habitats.
\end{abstract}

KEY WORDS: Hydroids - Benthic-pelagic coupling · Trophic ecology · Self-thinning rule · Ecosystem engineering $\cdot$ Animal forest $\cdot$ Benthic suspension feeder $\cdot$ Energy storage

\section{INTRODUCTION}

Population structure can change in order to optimize energy resource inputs. Food availability, competition, perturbations and a certain degree of stochasticity can influence these dynamics (Lewin 1986, Hughes 1989). In sessile suspension feeders, size distribution is related to the impact of the population on the water column and, consequently, the study of their dynamics can help in understanding the changes through time in benthic-pelagic coupling processes (Gili \& Coma 1998). Skewness, a measure of the asymmetry, can be used to compare different size-frequency distributions (Vermeij \& Bak 2000). Asymmetrical distributions are expected in populations with a higher percentage of small individuals, while more symmetric ones should be present during a shift toward larger sizes (Hughes \& Jackson 1985, 
Babcock 1991, Bak \& Meesters 1998, Adjeroud et al. 2007, Gori et al. 2011). Long-lived benthic suspension feeders play an important role in benthic-pelagic coupling, but their dynamics cannot be directly observed as their life cycles exceed the researchers' life spans. Short-lived species with similar population structure dynamics can be studied in order to validate theoretical models giving a more precise idea of the impact in the water column of small and large individuals.

Terrestrial or aquatic sessile species create structures (plant or animal forest) that enhance energy acquisition and minimize competition for space/ energy and predation. Intraspecific competition leads to changes in population structure in accordance with the availability of space and resources. In benthic suspension feeders, a relationship between resource capture and colony size has been observed (Kim \& Lasker 1997). One of the most general empirical rules related to intraspecific competition is the self-thinning rule (Yoda et al. 1963, White 1981). This general law was formulated for plant population biology, but has also been proven valid for some octocorals (e.g. Paramuricea clavata and Eunicella singularis; Linares et al. 2008). According to this rule, the density of survivors $(d)$ is related to their biomass $(w)$ by the power equation $w=K d^{\text {a }}$, where 'a' is a constant whose value lies between -1 and -2 and $\log K$ is mostly between 3.5 and 5 (Miyanishi et al. 1979). On the basis of this rule, a non-disturbed population subject only to intraspecific competition will then be expected to follow, during its life cycle, an ideal trajectory based on a power curve with an exponent between -1.3 and -1.8 , alternatively showing population structures characterized by low densities and large colonies or high densities and small colonies. In long-lived benthic suspension feeders, the theoretical trajectory of population structure can be extrapolated from the present data considering different populations as snapshots representing stages in a dynamic process of population growth and decline (Bak \& Meesters 1998), as Linares et al. (2008) did with $P$. clavata and E. singularis, or theoretically modelled on the basis of demographic population models as Bramanti et al. (2009) did with Corallium rubrum. In whatever case, due to the long life span of colonies and the slow dynamics of populations, the real time process in long-lived species can never be observed.

Passive suspension feeders are important components of benthic communities creating living 3dimensional structures called animal forests (Gili \& Coma 1998). They are considered surface dependent because their energy inputs depend mainly on the surface exposed to the main currents (Vogel 1981). In fast-growing species that depend on seasonal fluctuations (e.g. hydrozoans), the demographic parameters of the patch (i.e. size, number of polyps, density of colonies) respond to environmental seasonal changes in order to enhance prey capture during or just before the reproductive period and efficiently transform the carbon input into offspring (Gili \& Hughes 1995, Bavestrello et al. 2006). In long-lived species, maximal gonadal output coincides with maximum feeding surface (Coma et al. 1994), assuming the extrapolation of short cycles to long cycles to be valid. When benthic organisms share space, morphological adaptations appear over time (Buss 1979); in hydrozoans constrained by seasonal fluctuations, the colonies can alternate their morphology and population structure during the annual cycle (Boero \& Fresi 1986, Gili \& Hughes 1995, Bavestrello et al. 2006). Population strategy must adapt to food availability, creating the optimal patch structure at the right moment (Sousa 1979, Paine 1994, Pulliam 1996), having a prey capture rate proportional to their capture surface (Sebens 1982). One way of optimizing food capture and allocating more energy to the offspring of ephemeral species is to seasonally increase the feeding surface of the population by concentrating the captures in a low number of taller colonies. Rapid growth is a common strategy for erect organisms in the benthic community to avoid direct competition for space and food (Jackson 1977) and 3dimensional structures enhance the capture of prey (McMahon 1973). In seasonal environments, sessile organisms suffer strong energy input fluctuations, with periods of abundance and scarcity regulated by environmental factors (Rossi et al. 2006), and shortlived organisms adapt their life cycles to these seasonal trends (Margalef 1974).

The present work focuses on the potential use of the seasonal cycle of the fast-growing hydrozoan Eudendrium racemosum as a model for some aspects of the long-term dynamics of taxa such as gorgonians, alcyonarians, or hard corals that play an important role in benthic-pelagic coupling processes. We posed different questions to compare both long-term and short-term strategies. Can the changes in the demographic structure of populations of this hydrozoan be interpreted as an optimization of energy input coinciding with the reproductive period? Can this observation be connected with the optimization of the gonadal output in long-lived species? What is the importance of larger hydrozoan colonies in benthic-pelagic coupling and, consequently, on bio- 
geochemical cycles? May hydrozoan population dynamics be compared to the dynamics of long-lived species in order to evaluate their importance regarding benthic-pelagic coupling?

To answer these questions, 3 different approaches were simultaneously followed: the monitoring of population structure, the impact on the near-bottom seston of hydropolyps (feeding impact) and the energy storage change (in the form of lipids) during a seasonal cycle.

\section{MATERIALS AND METHODS}

\section{Hydrozoan species chosen, study area and environmental factors monitored}

Eudendrium racemosum is a Mediterranean athecate hydrozoan that has been widely studied in the last 25 yr (especially its trophic ecology; e.g. Boero \& Fresi 1986, Barangé 1988, Barangé \& Gili 1988, Gili et al. 2008, Di Camillo et al. 2012). It forms tree-like colonies (up to $12 \mathrm{~cm}$ ), with polyps that are $500 \mu \mathrm{m}$ wide and $650 \mu \mathrm{m}$ long. This cnidarian tends to be more abundant where currents are bi- or multidirectional (Boero \& Fresi 1986). The hydrocaulii arise from common stolons, forming homogeneous populations (Oliveira et al. 2000) that live between shallow-water calcareous and fleshy algal communities (infralittoral zone) (Boero \& Fresi 1986, Ballesteros 1992). The reproductive period is between May and October (Boero \& Fresi 1986, Barangé \& Gili 1988, Sommer 1992, Di Camillo et al. 2012). Like other hydrozoans, it is an opportunistic, non-selective carnivore in which prey capture range is limited only by prey size and mobility (Barangé 1988, Barangé \& Gili 1988, Di Camillo et al. 2012), and it also has a high energy input from phytoplankton (Gili et al. 2008). As a passive suspension feeder, the basic functions and structure may be directly compared with long-lived gorgonians, which are also clonal structures with polyps as the basic unit (Sebens 1982).

Our study was carried out in the Medes Islands, NE Spain $\left(43^{\circ} 3^{\prime} \mathrm{N}, 3^{\circ} 13^{\prime} \mathrm{E}\right)$ on a steep wall at a depth of between 3 and $6 \mathrm{~m}$, where a dense Eudendrium racemosum hydrozoan population is present (Gili \& Ros 1985). An accurate description of the environmental and biological characteristics of the water column in the sampling area is available in Rossi \& Gili (2005), and a description of the rocky shore annual community dynamics at this depth is available in Garrabou et al. (2002). The temperature at a depth of $5 \mathrm{~m}$ was recorded, as by Rossi \& Gili (2005), using water tem- perature profiles made 4 times per week with an inverted thermometer.

\section{Density and patch structure}

From February 1999 until February 2000 a 3.20 m long permanent transect line was followed monthly at a depth of 3.2 to $3.5 \mathrm{~m}$, and hydrocauli were measured and counted in 8 randomly placed squares of $40 \times 40 \mathrm{~cm}$ in order to obtain data on size structure and density $\left(\mathrm{m}^{-2}\right)$. Population was divided into 5 size classes: 0.5 to $2,2.1$ to $4,4.1$ to $6,6.1$ to $8 \mathrm{~cm}$ and $>8.1 \mathrm{~cm}$ height. At the same time, nudibranchs Flabellina affinis feeding on the polyps were counted in the same squares studied.

\section{Gut contents, morphology/size and total lipid sampling}

The sampling of gut contents, morphology and lipids was done the previous year. The sampling design was carried out in 2 different years (1997 to 1998 and 1999 to 2000) due to time constraints. We made the first observations on population dynamics, similar to those described in the previous subsection for the 1999 to 2000 analysis. Di Camillo et al. (2012) found the same trend in 2006 to 2008 in the Adriatic Sea; thus, we are confident that interannual variations are not major in this species and should not invalidate our sampling model. Furthermore, previous observations in the same study area were similar in both population dynamics and prey capture rates (Barangé 1988, Barangé \& Gili 1988, Barangé et al. 1989) and follow the same trends as in other areas (see Boero \& Fresi 1986 and Gili \& Hughes 1995 for a general picture; see Bavestrello et al. 2006 and Di Camillo et al. 2012 for specifics on the seasonal cycle of Eudendrium racemosum).

From April 1997 to April 1998, 10 hydrocauli were collected each month and fixed immediately in formaldehyde $(\sim 6 \%$, for the morphology and gut content analysis). For lipid analysis, 5 hydrocauli were collected monthly from April 1997 to June 1998 and preserved at 5 to $10^{\circ} \mathrm{C}$ on the boat and then deep-frozen with liquid nitrogen at the harbor (no more than $30 \mathrm{~min}$ passed at 5 to $10^{\circ} \mathrm{C}$ ). The samples were collected by SCUBA diving between $10: 00$ and $13: 00 \mathrm{~h}$ to avoid circadian rhythms, and 5 to $10 \mathrm{~min}$ before the end of each dive to prevent prey digestion. 


\section{Height of the colonies and polyp morphology variations throughout the annual cycle}

The height and width of the 10 hydrocauli were measured in the laboratory with a ruler under a binocular microscope $( \pm 0.5 \mathrm{~mm}$ precision $)$. Total extremity numbers were counted and classified according to the following categories (Sommer 1992, Oliveira et al. 2000):

(1) Pedicels: the step before growing polyps (the coenosarc full) or the step after the fall or predation of polyps (the coenosarc empty); no distinction between pedicels is reported here (only the total number of pedicels).

(2) Polyps: the hydranths are almost spherical, tentacles are completely developed, and the coenosarc has no empty spaces.

(3) Growing polyps: the coenosarc is continuous, and there is a quite well developed bulk on the edge, without tentacles and sometimes with a thin layer (perisarc) covering it.

(4) Senescent polyps: the hydranths are smashed and always empty, with clear degeneration of the crown tentacles (autotomy), and, in most cases, the coenosarc is not continuous or absent.

(5) Reproductive polyps (female and male; based on Sommer 1992).

\section{Height versus organic matter, dry weight and the $\mathrm{C} / \mathrm{N}$ ratio in the hydrocauli}

One-hundred hydrocauli were collected on 9 Apri 1998 and divided into 4 size classes: 0.5 to $2,2.1$ to 4 , 4.1 to 6 and $>6.1 \mathrm{~cm}$ (the size class $>8.1 \mathrm{~cm}$ was not present). The hydrocauli were kept in filtered seawater $(0.2 \mu \mathrm{m}$ mesh) for $14 \mathrm{~h}$ to empty gut contents. Then, 50 hydrocauli were used to determine the dry weight (DW) of each size class (heated for $24 \mathrm{~h}$ at $80^{\circ} \mathrm{C}$ ). Dry weights of colonies of different size classes were then used to calculate the mean colony weight for each month, in order to verify whether the monthly variations were in accordance with the selfthinning rule (see next subsection). To determine ash-free dry weight another 50 hydrocauli were first dried and weighed, and then combusted for $5 \mathrm{~h}$ at $500^{\circ} \mathrm{C}$ and weighed again to obtain the difference between the DW and AFDW. To determine the carbon and nitrogen contents of hydrocauli, the first 50 hydrocauli (already dried and weighed) were used and analyzed with a Carlo Erba Elemental Analyzer, following a procedure similar to that described by Rossi et al. (2011). Pearson's product-moment corre- lation was applied between hydrocauli height and organic matter, dry weight and carbon contents (Zar 1996).

\section{Population dynamics}

Analysis of skewness (Agostino's test R software, package 'moments'; Komsta \& Novomestky 2011) was performed on the size distribution of the population in different months during the year in order to evaluate whether structures were significantly asymmetrical. A significant positive value of skewness indicates a population with a high percentage of small individuals, while no significant skewness is expected when the sizes are normally distributed and large individuals are present in the population (Hughes \& Jackson 1985, Babcock 1991, Bak \& Meesters 1998, Adjeroud et al. 2007, Gori et al. 2011).

In order to verify the occurrence of the selfthinning process, mean colony weight for each month was plotted versus colony density (Linares et al. 2008) and the relation was calculated in order to compare the curve describing experimental data with a theoretical power curve with exponent -1.3 (Enquist et al. 1998, Muller-Landau et al. 2006). This plot allowed us to explore the existence of processes other than intraspecific competition in the population: if the population was only under the effect of intraspecific competition, all the points in the plot (representing the different months) should be close to the ideal trajectory line that goes from low biomass and high densities to high biomass and low densities according to a power curve with an exponent of -1.3. Points distant from the theoretical line indicate the presence of processes other than intraspecific competition.

\section{Gut contents and equations for trophic impact}

Gut contents were analyzed with a binocular microscope in 50 to 100 polyps from the 10 hydrocauli collected each month, following the methodology of Coma et al. (1994), Gili et al. (1996) and Rossi et al. (2004). The carbon content of the prey was calculated by estimating zooplankton biomass from its biovolume (Sebens \& Koehl 1984), using conversion factors to wet mass (1.025; Hall et al. 1970), dry mass (13\% of wet mass; Beers 1966) and to carbon content ( $45 \%$ of dry mass; Biswas \& Biswas 1979). Carbon content of the hydroid polyps was estimated applying the conversion factors from Paffenhofer (1968) as described in Barangé et al. (1989) and specifically 
calculated for Eudendrium racemosum in the present study (Table 1).

Different equations were used when the objective was to combine population dynamics with trophic impact through time. In the case of prey capture per square meter per day (np), the following equation was applied:

$$
\mathrm{np}=\sum_{\mathrm{SC} 1}^{\mathrm{SC} 5} P \times H_{\mathrm{SC}} \times D \times \operatorname{Pr} \times \operatorname{Co}(1-3)
$$

where SC is size class (height of the hydrocauli: $\mathrm{SC} 1=0.5$ to $2 \mathrm{~cm}, \mathrm{SC} 2=2.1$ to $4 \mathrm{~cm}, \mathrm{SC} 3=4.1$ to $6 \mathrm{~cm}, \mathrm{SC} 4=6.1$ to $8 \mathrm{~cm}, \mathrm{SC} 5 \geq 8.1 \mathrm{~cm}), P$ is the average number of polyps per centimeter of hydrocauli, $H_{\mathrm{SC}}$ is the average colony size (height of the hydrocauli: $\mathrm{SC} 1=1.5 \mathrm{~cm}, \mathrm{SC} 2=3.5 \mathrm{~cm}, \mathrm{SC} 3=$ $5.5 \mathrm{~cm}, \mathrm{SC} 4=7.5 \mathrm{~cm}, \mathrm{SC} 5=9 \mathrm{~cm}), D$ is the number (density) of hydrocauli per square meter, $\mathrm{Pr}$ is the number of prey per polyp, and Co(1-3) is the conversion factor for the digestion times, number of times per day $\left(1=7 \mathrm{~h}\right.$ of digestion at $14^{\circ} \mathrm{C}$ [considered winter temperature; S. Rossi unpubl. data], 3.4 times per day; $2=5 \mathrm{~h}$ of digestion at $18^{\circ} \mathrm{C}$ [considered spring and autumn temperatures; Barangé \& Gili 1988], 4.8 times per day; $3=3 \mathrm{~h}$ of digestion at $22^{\circ} \mathrm{C}$ [considered summer temperature; Barangé \& Gili 1988], 8 times per day, following the equations of Rossi et al. 2004, with 3 digestion temperatures simulating the seasonal trends of the environment [see Rossi \& Gili 2005, their Fig. 3A]). Extrapolations were made on the basis of the temperatures registered monthly at a depth of $5 \mathrm{~m}$ (see also Garrabou et al. 2002).

In order to obtain the milligrams of $\mathrm{C}$ per square meter per day the same equation was used substituting prey number (np) with prey biomass (pb, in $\mathrm{mg} \mathrm{C}$ $\mathrm{m}^{-2} \mathrm{~d}^{-1}$ ) such that:

$$
\mathrm{pb}=\sum_{\mathrm{SC} 1}^{\mathrm{SC} 5} P \times H_{\mathrm{SC}} \times D \times W_{\mathrm{pr}} \times \operatorname{Co}(1-3)
$$

where $W_{\text {pr }}$ is the weight in milligrams of C per polyp entry as prey captured (monthly from April 1997 to April 1998).
In order to transform the data into milligrams of $\mathrm{C}$ (prey) per milligrams of $\mathrm{C}$ (hydrozoan population) per square meter per day, the relations between height $(\mathrm{cm})$ and milligrams of $\mathrm{C}$ of the hydrocauli for each size class were used:

$$
\sum_{\mathrm{SC} 1}^{\mathrm{SC} 5} \mathrm{pb} \times H_{\mathrm{SC}} \times D \times \mathrm{RF}_{\mathrm{SC}}
$$

where $\mathrm{RF}_{\mathrm{SC}}$ is obtained on the basis of the height versus $\mathrm{C}$ regression curve shown in Table 1.

\section{Total lipids}

The 5 hydrocauli collected for biochemical purposes were lyophilized at $-100^{\circ} \mathrm{C}$ and 100 mbar for $12 \mathrm{~h}$. Only the hydrocauli without polyps were weighed in a microweigher (range of 1.0 to $8.0 \mathrm{mg}$ hydrocauli DW). Extraction and quantification of the total lipids were carried out according to Barnes \& Blackstock's (1973) protocols, following similar protocols by Rossi et al. (2006) and Rossi \& Tsounis (2007). The dry hydrocauli were homogenized in $6 \mathrm{ml}$ of chloroform:methanol $(2: 1 \mathrm{v}: \mathrm{v})$, and lipids were quantified using cholesterol as a standard.

\section{Statistics}

For statistical comparison 2 periods were considered: the reproductive and non-reproductive periods (presence or absence of gonads; Sommer 1992) (Fig. 1). One- and 2-way ANOVAs with Scheffé's post hoc test were used to test differences in total extremities, number of different polyps, height of the colonies, trophic impact and total lipids. The data were not distributed normally and had different variances but met both of these criteria for parametric analysis after logarithmic transformation (BrownForsythe test and Levene test, $\mathrm{p}=0.05$; Shapiro-Wilk test, $p=0.1$ ), thus permitting the use of an ANOVA (Zar 1996). The program used was the STATISTICA 6.0 software package.

Table 1. Eudendrium racemosum. Regression curves calculated for the hydrocaulus height (in cm) versus dry weight (DW, in

\begin{tabular}{|c|c|c|c|}
\hline Relationship & Regression curve & $\mathrm{R}^{2}$ & $\mathrm{p}$ \\
\hline Height vs. DW & $\mathrm{DW}=-2.969+(1.395 \times$ height $)+\left(0.436 \times\right.$ height $\left.^{2}\right)$ & 0.597 & $<0.019$ \\
\hline Height vs. OM & $\mathrm{OM}=-2.158+(1.026 \times$ height $)+\left(0.225 \times\right.$ height $\left.^{2}\right)$ & 0.581 & $<0.023$ \\
\hline Height vs. C & $\mathrm{C}=-0.130+(0.288 \times$ height $)$ & 0.608 & $<0.005$ \\
\hline
\end{tabular}
$\mathrm{mg})$, organic matter (OM, in $\mathrm{mg}$ ) and carbon $(\mathrm{C}$, in $\mathrm{mg}$ ) relations (sampling done in December 1998, see 'Materials and methods') 


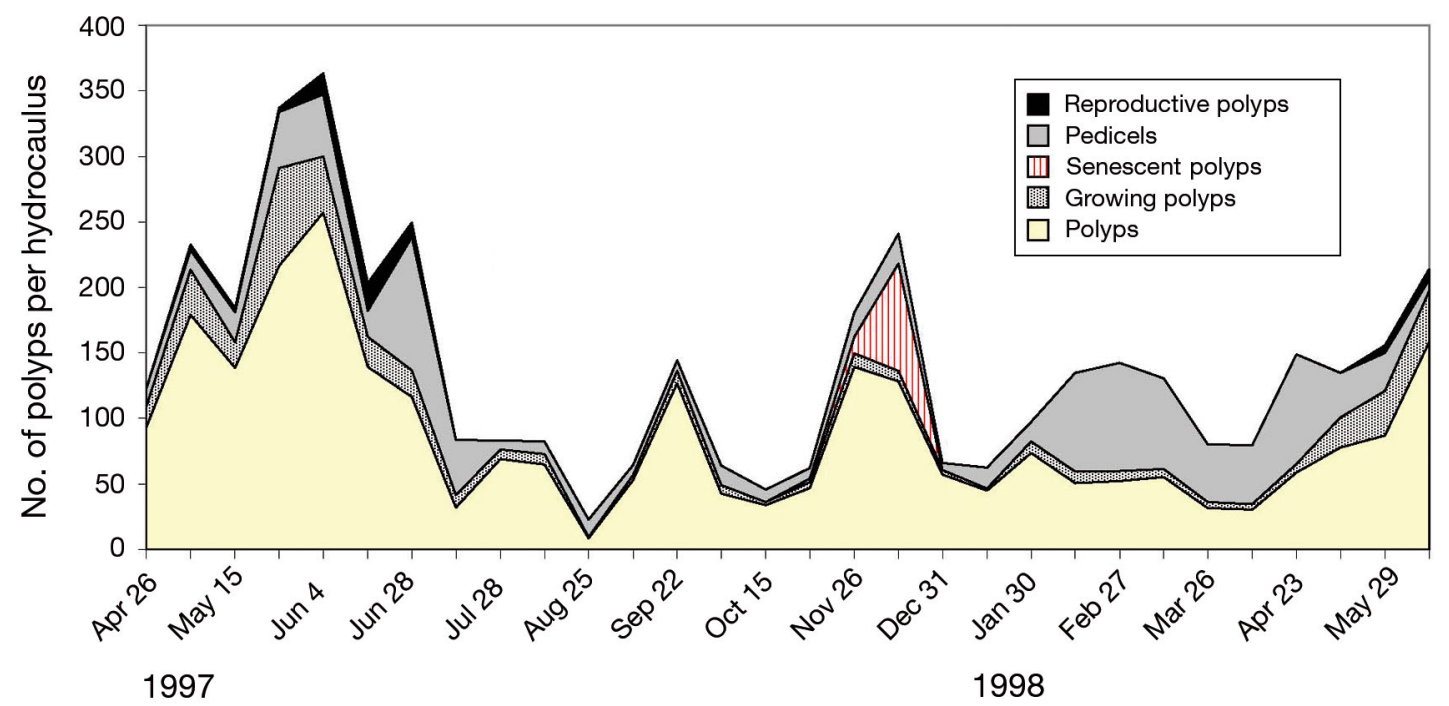

Fig. 1. Eudendrium racemosum. Quantification of different stages of polyps in the hydrocauli throughout the 1997/1998 cycle, all sampling times. Cumulative mean values per hydrocaulus. Gender of reproductive polyps (male and female) was not distinguished. Pedicels are hydrocauli without polyps. Senescent polyps show extremities in which the polyp is clearly deteriorated or absent. Growing polyps have a prominent bulk on the edge. Polyps are normal as described in Oliveira et al. (2000)

\section{RESULTS}

\section{Polyp variations throughout the annual cycle}

Fig. 1 shows the distribution of different extremities found in the hydrocauli of colonies of Eudendrium racemosum during the annual cycle. During the reproductive period, the number of total extremities is higher $(240 \pm 136 \mathrm{SD})$ than during the rest of the year $(105 \pm 78 \mathrm{SD})$ (2-way ANOVA, $F_{(1,308)}=$ $118.00 ; \mathrm{p}<0.0005)$. Distribution of different extremities in the hydrocauli was analyzed taking into account each type of extremity (as described in Sommer 1992, Oliveira et al. 2000):

(1) Reproductive polyps: reproductive gonophores were found from May to June in both years (Fig. 1); in July 1997, we still found some reproductive polyps, but they were clearly in a senescent phase. The number of gonads per hydrocauli was lower in 1998. The existence of reproductive polyps has been considered a threshold for the analysis of the life cycle.

(2) Pedicels: pedicels were significantly more abundant in June to July 1997 and in February to April 1998 (Fig. 1) than in the other months (2-way ANOVA, $\left.F_{(14,295)}=14.88 ; \mathrm{p}<0.0005\right)$.

(3) Senescent polyps: these types of polyps were found only in late November and December 1997 (Fig. 1). They became highly abundant until the deterioration of the entire extremities.

(4) Growing polyps: during the reproductive period these are more abundant $(35 \pm 27 \mathrm{SD}$ ) than during the rest of the year $(7 \pm 7 \mathrm{SD})$ (2-way ANOVA, $\left.F_{(14,295)}=19.13 ; \mathrm{p}<0.0005\right)$.

(5) Polyps: polyps are more abundant in May to June (162 $\pm 103 \mathrm{SD})$ than during the rest of the year $(62 \pm 52 \mathrm{SD})\left(2\right.$-way ANOVA, $F_{(14,295)}=13.53 ; \mathrm{p}<$ $0.0005)$; in July there is a sharp decrease and recovery in late September; the same tendency is observed between October and late December (Fig. 1).

\section{Height versus organic matter, dry weight and $\mathrm{C} / \mathrm{N}$ ratios in the tissue}

Table 2 shows the results for the amounts of dry weight, organic matter, carbon and nitrogen found per size class. These data are needed for the equations involving energy input per milligram of C. The height versus dry weight and organic matter relations better fit a power curve. The 3 relationships explain almost $60 \%$ of the variance, with a probability of $<0.05$, especially the height versus C relation (Table 1). In the sampling time (December 1998), colonies were all $<8 \mathrm{~cm}_{\text {; }}$ the data for the colonies $>8 \mathrm{~cm}$ height were extrapolated from these equations.

\section{Height of the hydrocauli}

The relationship between mean monthly temperature and mean hydrocauli height tends to increase 
Table 2. Eudendrium racemosum. Dry weight (DW), organic matter (OM), carbon (C) and nitrogen (N) contents of hydrocauli of different size classes (means $\pm \mathrm{SD}$ )

\begin{tabular}{|lcccc|}
\hline $\begin{array}{l}\text { Size class } \\
(\mathrm{cm})\end{array}$ & $\begin{array}{c}\text { DW } \\
(\mathrm{mg})\end{array}$ & $\begin{array}{c}\mathrm{OM} \\
(\mathrm{mg})\end{array}$ & $\begin{array}{c}\mathrm{C} \\
(\mathrm{mg})\end{array}$ & $\begin{array}{c}\mathrm{N} \\
(\mathrm{mg})\end{array}$ \\
\hline $0.5-2$ & $1.8 \pm 0.9$ & $1.0 \pm 0.4$ & $0.4 \pm 0.2$ & $0.1 \pm 0.1$ \\
$2.1-4$ & $2.4 \pm 1.3$ & $1.2 \pm 0.6$ & $0.6 \pm 0.2$ & $0.2 \pm 0.1$ \\
$4.1-6$ & $11.4 \pm 5.0$ & $6.6 \pm 3.3$ & $1.8 \pm 1.0$ & $1.1 \pm 0.2$ \\
$>6.1$ & $20.7 \pm 11.7$ & $12.0 \pm 6.8$ & $3.9 \pm 2.1$ & $1.6 \pm 0.3$ \\
\hline
\end{tabular}

to become statistically significant $\left(\mathrm{R}^{2}=0.66, \mathrm{p}<\right.$ $0.05 ; \mathrm{N}=6$ ) only in the April to June period (both in 1997 and 1998; Fig. 2) which corresponds to thermocline formation [height $(\mathrm{cm})=0.37 \times$ temperature - 1.09]. In the second year of sampling (1998), the temperature increase (April to May) is $>3^{\circ} \mathrm{C}$, and this change is in parallel with the increase by almost $2 \mathrm{~cm}$ in the mean height of the population.

Maximum height of hydrocauli was measured in June (1997 and 1998), while minimum height was measured in April 1998, followed by a sudden increase shortly thereafter. The colonies were taller $($ mean $=5.73 \mathrm{~cm})$ during the reproductive period (May to June, considering the presence of reproductive polyps, see below) compared with the rest of the annual cycle $($ mean $=4.04 \mathrm{~cm})$ (2-way ANOVA, $\left.F_{(1,308)}=109.00 ; \mathrm{p}<0.0005\right)$. The hydrocauli were 2.5

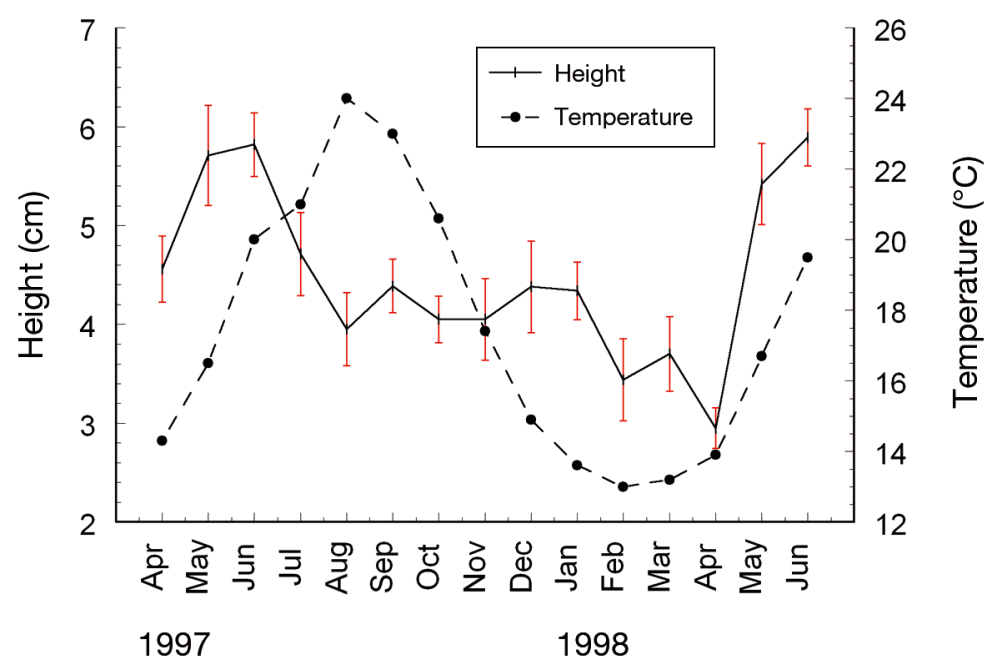

Fig. 2. Eudendrium racemosum. Temperature $\left({ }^{\circ} \mathrm{C}\right)$ and height of the hydrocauli (distance between the base and the tip of the colony, in $\mathrm{cm}$ ) in the 1997/1998 cycle of E. racemosum (mean monthly values \pm SD). There is a significant relationship only in the spring months, coinciding with the reproductive period to 3.5 times higher than they were wide over the whole cycle, with no seasonal differences. The maximum number of polyps coincided with the maximum height of the colonies.

\section{Population dynamics}

Variations in colony density are shown in Fig. 3. The patch structure in February, March and April was characterized by high density, small mean colony size (Fig. 3) and a size distribution in which most colonies belonged to small size classes. Analysis of skewness confirmed a significant value of asymmetry of the size distributions (Table 3). After April, the structure of the patch changed, becoming less dense, with a higher mean colony size and with a greater presence of large classes: in May, June and July the density was low (Fig. 3) and the size distributions were not significantly skewed until July 1999 (Table 3). The appearance of nudibranchs hatching on the Eudendrium racemosum branches seemed to be related to the presence of larger colonies and determined the decrease in population density and mean colony size recorded in August and September (Fig. 3). The nudibranchs were observed feeding on the polyps and reproductive polyps. The densities of nudibranchs were $1.06 \pm 3.4 \mathrm{~m}^{-2}$ in July, $1.34 \pm$ $6.67 \mathrm{~m}^{-2}$ in August and $1.12 \pm 3.6 \mathrm{~m}^{-2}$ in September 1999, while they were absent during the rest of the cycle. In October, colony density and mean size started to return to values similar to those found in April (Fig. 3); also the distribution was not yet significantly skewed (Table 3), meaning that the frequency of small-sized colonies had yet to reach maximum levels. November, December, January and February showed high densities and small mean colony sizes, and the predominance of small colonies led to significantly skewed size distributions (Table 3).

In Fig. 4, the curve describing the experimental data was drawn without taking into account the months of August and September (when the density of nudibranchs is higher). It is a power curve with an exponent of -1.2884 that is extremely similar to the theoretical curve expected if the population were to follow the self-thinning rule (exponent -1.3). Points representing the months from February 1999 to July 1999 and 
from October 1999 to February 2000 are located close to the self-thinning line, suggesting that in these periods the population is only subject to intraspecific competition processes. The only 2 points that are far from the ideal trajectory are those representing the months of August and September, when nudibranchs were observed preying on larger colonies.

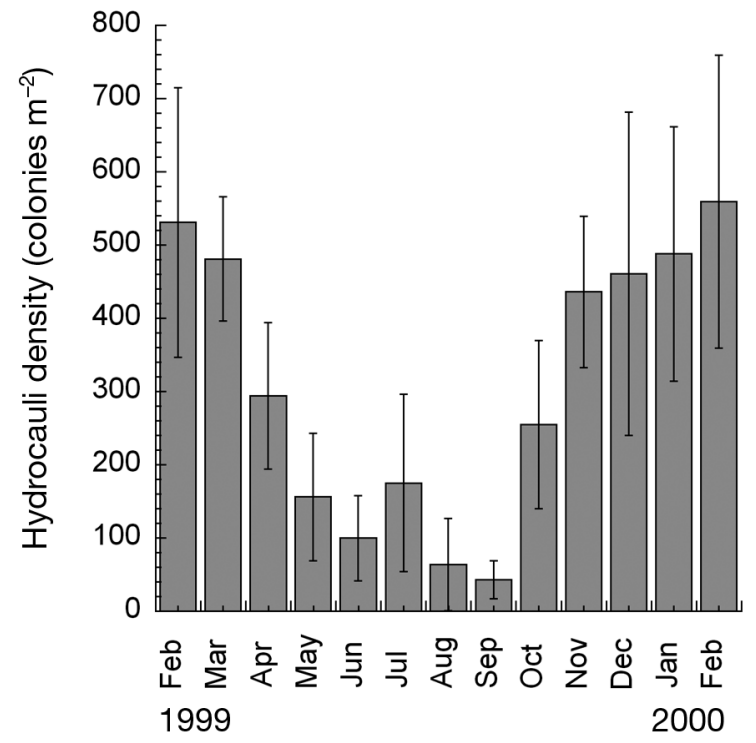

Fig. 3. Eudendrium racemosum. Hydrocauli density in the 1999/2000 cycle (number of hydrocauli $\mathrm{m}^{-2}$ ). Density is inversely proportional to the height of the hydrocauli. Monthly means $\pm \mathrm{SD}$

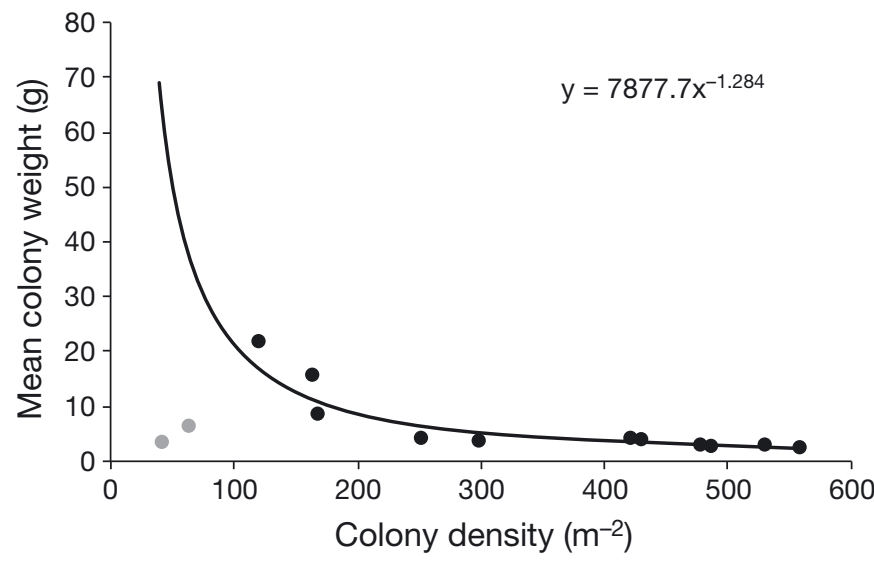

Fig. 4. Eudendrium racemosum. Relationship between colony density and colony dry weight of the experimental data, excluding August and September (gray points), when a high presence of nudibranchs Flavellina affinis-predators of E. racemosum-was observed. It is almost the same as the ideal trajectory representing the self-thinning rule $\left(w=K d^{\text {a }}\right.$, where $w$ is mean weight, $K$ is a constant, $d$ is density of survivors and ' $a$ ' is a constant whose value lies between -1 and 2

\section{Eudendrium racemosum trophic impact on the seston throughout the annual cycle}

The impact of the Eudendrium racemosum population on the seston in the water column is shown in Fig. 5. Maximum estimated prey capture was recorded in the reproductive period $\left(273 \times 10^{3}\right.$ prey $\mathrm{m}^{-2} \mathrm{~d}^{-1}$ ) coinciding with the change in structure and

Table 3. Eudendrium racemosum. Skewness values for the size distributions of E. racemosum in different months. Significance of skewness was calculated with D'Agostino's test. Size distributions with a significant value of skewness indicate the abundance of small size colonies, while in distributions with non-significant $(\mathrm{p}>0.05)$ skewness, large size colonies are more abundant

\begin{tabular}{|lcc|}
\hline Month & Skewness & $\mathrm{p}$ \\
\hline $\mathbf{1 9 9 9}$ & & \\
Feb & 1.46 & $<0.001$ \\
Mar & 1.06 & $<0.001$ \\
Apr & 1.13 & $<0.001$ \\
May & 0.11 & $>0.05$ \\
Jun & -0.14 & $>0.05$ \\
Jul & 0.25 & $>0.05$ \\
Aug & -0.35 & $>0.05$ \\
Sep & 0.18 & $>0.05$ \\
Oct & 0.03 & $>0.05$ \\
Nov & 0.59 & $<0.001$ \\
Dec & 0.96 & $<0.001$ \\
Jan & 0.99 & $<0.001$ \\
$\mathbf{2 0 0 0}$ & & \\
Feb & 0.95 & \\
\hline
\end{tabular}

Table 4. Eudendrium racemosum. Calculation of the impact in the water column (prey capture $\mathrm{m}^{-2} \mathrm{~d}^{-1}$ ) throughout the 1997/1998 cycle of E. racemosum (means \pm SD; according to Eq. 1)

\begin{tabular}{|lrr|}
\hline Month & Prey $\mathrm{m}^{-2} \mathrm{~d}^{-1}$ & $\mathrm{SD}$ \\
\hline $\mathbf{1 9 9 7}$ & & \\
Apr & 37900 & 11900 \\
May & 126000 & 54800 \\
Jun & 372000 & 92000 \\
Jul & 265000 & 34100 \\
Aug & 32000 & 34300 \\
Sep & 60900 & 57900 \\
Oct & 97200 & 67500 \\
Nov & 157000 & 57000 \\
Dec & 109000 & 18500 \\
$\mathbf{1 9 9 8}$ & & \\
Jan & 109000 & 32000 \\
Feb & 68200 & 48300 \\
Mar & 112000 & 35700 \\
Apr & 65900 & 2660 \\
\hline
\end{tabular}


density of the patch (Fig. 3) and the surface capture of each hydrocaulus (considered the number of polyps $\mathrm{m}^{-2}$ ). There is a significant difference between the estimations for this period and those for the rest of the year $\left(101 \times 10^{3}\right.$ prey m $\left.\mathrm{m}^{-2} \mathrm{~d}^{-1}\right)(2$-way ANOVA, $\left.F_{(1,25)}=7.77 ; \mathrm{p}<0.01\right)$. The estimation per month appears to be more acute, the impact in May to June being $2.99 \times 10^{7}$ prey $\mathrm{m}^{-2} \mathrm{mo}^{-1}$ as opposed to $7.53 \times 10^{6}$ prey $\mathrm{m}^{-2} \mathrm{mo}^{-1}$ in the non-reproductive period (Table 4). The carbon input is also higher in the reproductive period $\left(30.7 \mathrm{mg} \mathrm{m}^{-2} \mathrm{~d}^{-1}\right)$ than in the other months (10.2 $\left.\mathrm{mg} \mathrm{C} \mathrm{m}^{-2} \mathrm{~d}^{-1}\right)$ (2-way ANOVA, $\left.F_{(1,25)}=7.95 ; \mathrm{p}<0.0093\right)$. When the renewed biomass estimated based on milligrams of $\mathrm{C}$ values of the hydrocauli was calculated, we found higher values in

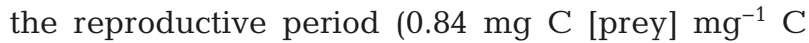
[hydrozoan] $\mathrm{m}^{-2} \mathrm{~d}^{-1}$ ) than in the non-reproductive one $\left(0.19 \mathrm{mg} \mathrm{C}^{\mathrm{C}}\right.$ [prey] $\mathrm{mg}^{-1} \mathrm{C}$ [hydrozoan] $\mathrm{m}^{-2} \mathrm{~d}^{-1}$ ) (2-way ANOVA, $\left.F_{(1,25)}=12.70 ; p<0.0015\right)$. Fig. 5 shows this turnover of energy: the last 3 size classes (from 4.1 to $>8.1 \mathrm{~cm}$ height) represent most of the energy input. During the rest of the year, the pattern is regular for all size classes.

\section{Total lipids}

The total lipids in the hydrocaulus varied seasonally throughout the year (Fig. 6). Comparing the reproductive and non-reproductive groups (May to June 1997 and 1998 and rest of the cycle) there is a significant difference (May to June 1997: $136.8 \pm$ 66 SD $\mu$ g lipid $\mathrm{mg}^{-1}$ AFDW; July 1997 to April 1998: $70.8 \pm 38$ SD $\mu$ g lipid $\mathrm{mg}^{-1}$ AFDW; May to June 1998: $137 \pm 81 \mathrm{SD} \mu \mathrm{g}$ lipid $\mathrm{mg}^{-1}$ AFDW) (2-way ANOVA, $\left.F_{(2,114)}=20.68 ; \mathrm{p}<0.0005\right)$.

\section{DISCUSSION}

\section{Seasonal trends of the Eudendrium racemosum population and trophic dynamics}

The hydrozoan Eudendrium racemosum changes its hydrocaulus height, population density and the morphology of polyps in relation with the reproductive period. The general seasonal dynamics did not change in the 2 different years of samling, also

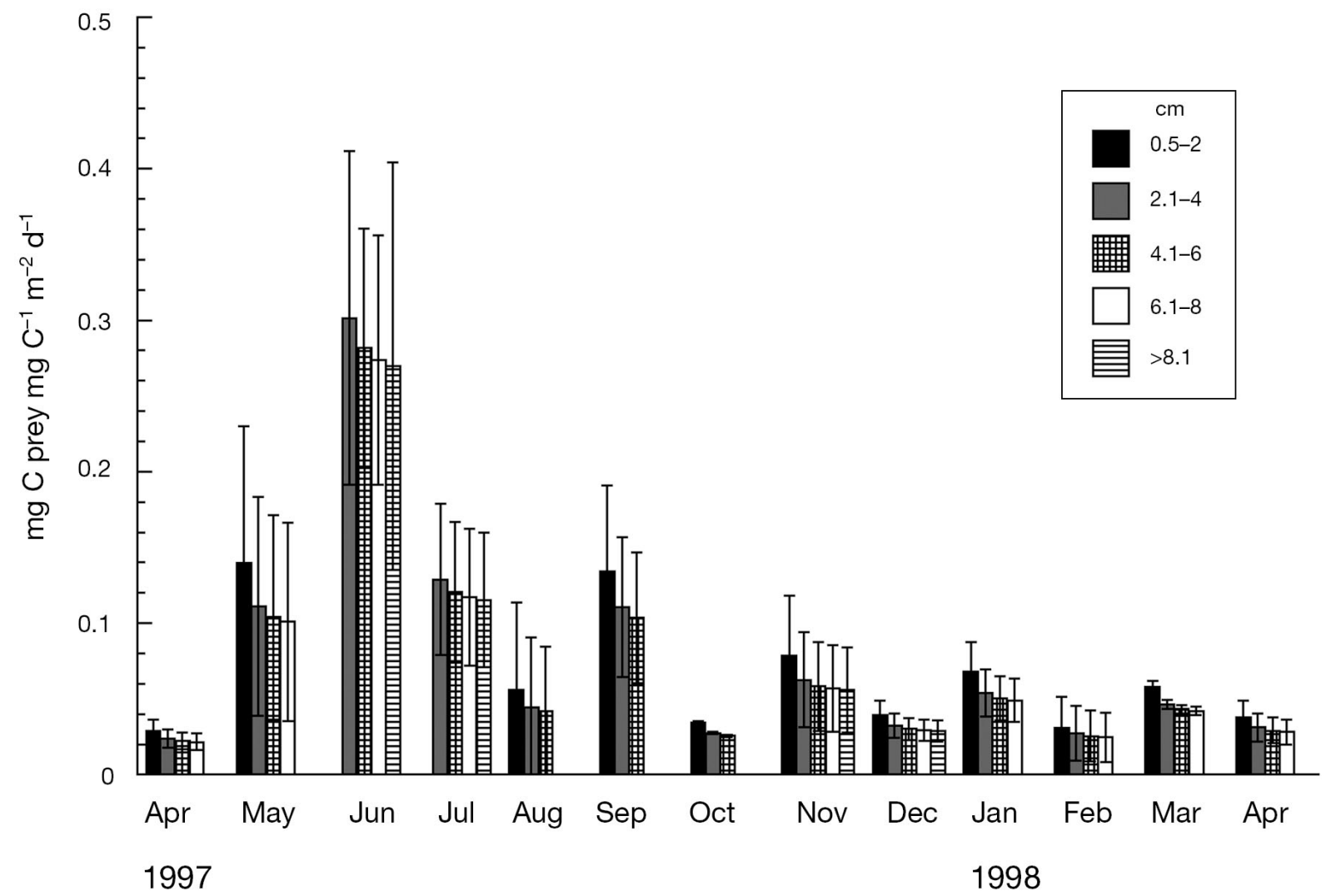

Fig. 5. Eudendrium racemosum. Impact of different colony size classes (see key on figure) in the water column throughout the $1997 / 1998$ cycle (means \pm SD). Larger colonies have a larger impact on the water column even if they are less abundant. Calculations from Eq. (3) 


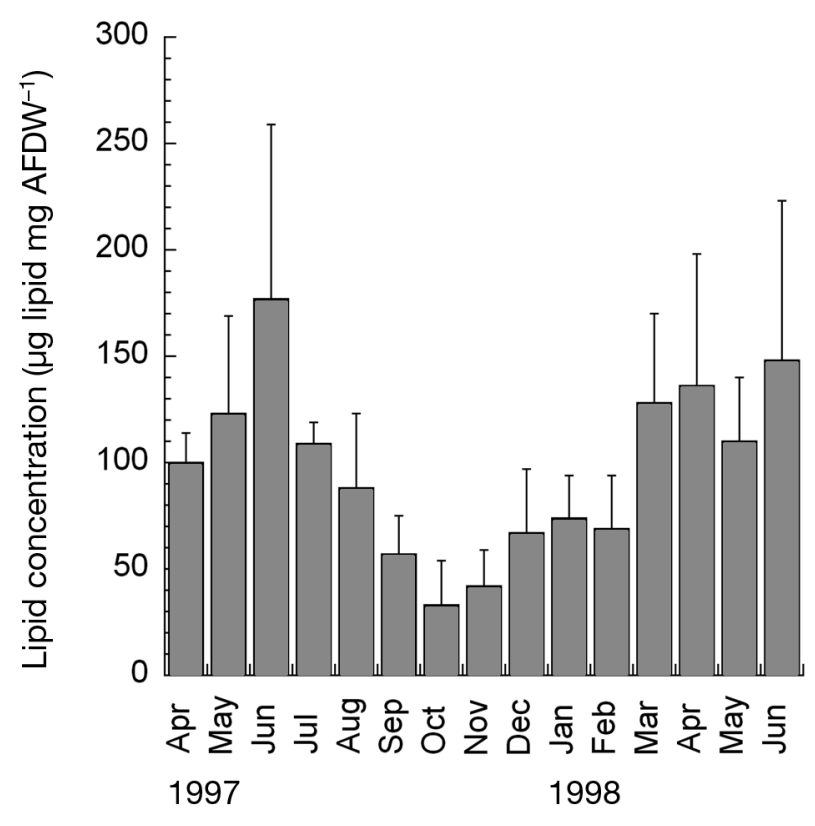

Fig. 6. Eudendrium racemosum. Lipid storage in the hydrocaulus of E. racemosum ( $\mu \mathrm{g}$ total lipid $\mathrm{mg}^{-1}$ dry weight) throughout the 1997/1998 cycle. Energy is stored coinciding with the reproductive period (April-July). The autumn period shows the lower values of lipids, coinciding with the autumn trophic crisis. Monthly means \pm SD

shown in previous work (Di Camillo et al. 2012). In fact, a general pattern of seasonality, with only small temporal offsets (weeks), may be observed in most Mediterranean hydrozoans (Bavestrello et al. 2006). As a consequence, the relation between growth patterns and capture rates shown for several cnidarian species (McFadden 1986, Hunter 1989, Sebens \& Johnson 1991, Patterson 1992, Helmuth \& Sebens 1993) is also reflected in the seasonal changes in polyp morphology and height of E. racemosum, linked to the optimization of capture rates during the most important part of the life cycle. In the reproductive period, the hydrocauli are taller; the polyp, growing polyp and pedicel/hydrocaulus density and mean colony weight increases; and the density of the colonies decreases. The growing polyps are also more abundant in the reproductive period because of their transformation into polyps. These features lead to an increase in the number of polyps (feeding surface) per square meter. As rates of prey contact depend on the surface area of the capture structure (Sebens 1982), the increase in polyp number and consequent increase in colony size during the reproductive period result in an increase in capture efficiency. This hypothesis is supported by the fact that lipids are almost twice as abundant in the hydro- caulus during the reproductive period than during the rest of the year.

The appearance of senescent polyps (together with the increase in size of the hydrocauli) only in November and December could be a response of the population to a second bloom in early autumn that disappears shortly thereafter (Ribera d'Alcalá et al. 2004). Notwithstanding the increased food supply, hydrocauli do not reach the same size as in spring. In general, a low number of species of hydrozoans and hydrocauli appear in late autumn-early winter in warm temperate seas (Bavestrello et al. 2006). According to recent studies (Rossi et al. 2006, Gori et al. 2007, Rossi \& Tsounis 2007), the hydroids may also be affected by a late autumn-early winter trophic crisis observed in warm temperate seas, in which the particulate organic matter concentration is very high, but its quality is very poor (Grémare et al. 1997, Rossi et al. 2003). In Llobet et al. (1991), most of the epiphytic hydrozoans of the algae Halimeda tuna are of highly variable abundance throughout the seasonal cycle, but some of their maximum pedicel numbers are in strong coincidence with the periods before and after reproduction. Coma et al. (1992) recorded the same trend in the hydrozoan Halecium pusillum, and also in the case of Campanularia everta, where the proportion of pedicels without hydrants/total extremities is higher before and after reproduction. Another recent study of Eudendrium racemosum in the Adriatic Sea corroborates the trend observed in our study (Di Camillo et al. 2012). We can conclude that the formation of the pedicel accelerates when the population is constructing new polyps and that, after the reproductive effort, predation, senescence, or the trophic shadow cast by other benthic organisms again cause the appearance of pedicels.

Sexual reproduction in hydrozoans in temperate waters is typically restricted to a specific season of the year (Boero \& Fresi 1986, Calder 1990, Llobet et al. 1991, Coma et al. 1996, Calder \& Maÿal 1998), and the same species could develop different seasonal strategies depending on environmental- and depthrelated conditions (Gili \& Hughes 1995). This could explain the different behaviors of Eudendrium racemosum at our study site (Medes Islands) and those referenced by Boero \& Fresi (1986) and Di Camillo et al. (2012). Whilst Boero \& Fresi (1986) observed the population disappearing in winter and sexually reproducing up to October (neither of which were observed in our fieldwork in 1997/1998 or in 1999/ 2000), Di Camillo et al. (2012) found a wider fertility period between April and September (in concurrence with our present results). Minimal density of 
hydrocauli in winter and maximal density in summer were also observed by Barangé \& Gili (1988) in the same study area in the late 1980s. Another Eudendrium species (E. glomeratum) also shows clear seasonal dynamics, but its reproductive period seems to be related to the early autumn peak of productivity, starting with thermocline mixing (Boero et al. 1986).

Changes in colony morphology and size are related to consequent changes in population density. The changes occur in accordance with the self-thinning rule (Yoda et al. 1963, Miyanishi et al. 1979, White 1981), indicating that the process is driven by intraspecific competition. The mechanism underlying these variations could thus be the capture rate optimization that leads to an increase in size of the colonies and a consequent decrease in density due to intraspecific competition. Plotting mean weight versus colony density, excluding the data of August and September, gives a power curve with an exponent of -1.2884 ; this is the equation expected by the selfthinning rule (Fig. 4). It is worth noting that 2 months (August and September) lie far from the theoretical line representing the self-thinning rule (Linares et al. 2008). If only intraspecific competition processes were driving density changes, we would have expected all the points representing the population structure of different months to be close to the theoretical line. So, in August and September some process other than intraspecific competition apparently drives the population dynamics of Eudendrium racemosum. The explanation could lie in predation by nudibranchs that feed on the polyps of hydrozoans. The feeding of nudibranchs on hydrozoans or other suspension feeders has been described in many studies, although it has rarely been quantified (MacLeod \& Valiela 1975, Bryan et al. 1998, Di Camillo et al. 2012). This phenomenon has been observed for $E$. racemosum (Barangé et al. 1989), and the hydrozoans have no effective mechanisms of defense against the predator (Martin 2003, Martin \& Walther 2003). In our observations from July to September the density of nudibranch feeding on the polyps and of hatching on the hydrocauli was $>1$ nudibranch $\mathrm{m}^{-2}$, considerably lower than the recent results by $\mathrm{Di}$ Camillo et al. (2012), in which the density of the nudibranchs Cratena peregrina was almost 10 ind. $\mathrm{m}^{-2}$ (feeding up to 500 polyps $\mathrm{d}^{-1}$ ). Notwithstanding the 1 order of magnitude lower density, changes in the population structure of the Medes Islands due to nudibranchs are similar to the description by Di Camillo et al. (2012). The appearance of the predators accelerates the decrease in the number of polyps, the density of hydrocauli and, in the end, the disappearance of the 6.1 to 8 and $>8.1 \mathrm{~cm}$ size classes (taller colonies are more exposed to predators). Predation effects are therefore coupled with the scarcity of available food in determining the decrease in density and the disappearance of large size classes. Many hydroids decrease in density and cannot capture prey in shallow waters in summer because of the summer trophic crisis, in which poor water movement and the rise in water temperature force a dormant stage in these and other suspension feeders (Coma et al. 2000).

The description of size-frequency structure by means of skewness analysis supplied additional information on the dynamics of the population of Eudendrium racemosum, showing in the course of the annual cycle an alternation in distributions characterized by higher frequencies of alternately large and small colonies. The same dynamics of cyclic abundances of small and large colonies (young and old) have theoretically been forecast for Corallium rubrum by means of a mathematical model (Bramanti et al. 2009) and have been explained as an effect of exploitation (Santangelo et al. 2007, Linares et al. 2010) or anthropogenic disturbance (McClanahan \& Muthiga 1988, Hughes et al. 2003, Blackwood et al. 2010). In long-lived species, the extremely slow life cycle does not allow direct observation of the forecasted dynamics, and the use of simulations, based on demographic models, is the only way to understand the long-term patterns (Heppel et al. 1996, Fujiwara \& Caswell 2001, Santangelo et al. 2004, Santangelo \& Bramanti 2006, Arrigoni et al. 2011). Dynamics of fast-growing species with annual life cycles make it possible to observe in real time the same processes driving the dynamics of slow-growing species. E. racemosum can thus be considered a living real time model to evaluate the hypotheses made for other species. The importance of the discovery of the occurrence of self-thinning processes lies in the possibility of extending the validity of a process occurring in plants to animal populations, strengthening the conceptual connection between vegetal and animal forests and consequently giving marine ecologists the possibility of applying conceptual tools developed in forest sciences.

\section{The importance of being largest}

Now that we have quantified the variability of the feeding surface in a patch of Eudendrium racemosum, we can calculate its predatory impact. Results suggest that E. racemosum plays an important role in 
energy transfer from the water column to benthic littoral communities. Predation impact on the seston by individual colonies is negligible, but considering the total feeding surface, patch capture rates are very high.

Considering the change in hydrocaulus height and the number of polyps per centimeter, the energy input in the reproductive period (May to June 1997) is different from that during the rest of the annual cycle. The 344 prey per hydrocaulus calculated for the reproductive period ( $38.3 \mu \mathrm{g} \mathrm{C}$ hydrocaulus ${ }^{-1}$ ) is 3 times greater than that in the non-reproductive period, with 117 prey hydrocaulus ${ }^{-1}$ (and almost 4 times less $\mathrm{C}$ entry, $10.9 \mu \mathrm{g} \mathrm{C}$ hydrocaulus ${ }^{-1}$ ). The diel mass-specific ingestion rate (in \%) also varies according to the patch dynamics of Eudendrium racemosum $_{i}$ higher values are reached during the reproductive period (45 to $120 \%$ ) than during the non-reproductive period (10 to $40 \%$ ), and are among the highest for hydrozoans (Gili \& Coma 1998). The values coincide with those previously recorded by Barangé \& Gili (1988) in the non-reproductive period (39\%, values from July and September). Di Camillo et al. (2012) also found a coincidence of this predatory impact and the reproductive period in the Adriatic Sea. This reinforces the hypothesis that there is a favorable period when the structure of the hydrocauli change, enhancing the feeding capability of the hydrozoan. The higher presence of lipids in the hydrocauli confirm this. This can also be extrapolated to gorgonians. It has been shown that lipid contents in young gorgonians (Paramuricea clavata, $<10 \mathrm{~cm}$ tall, not reproductive) are 25 to $35 \%$ lower in the same period with respect to larger ones (females vs. young colonies; Rossi et al. 2006). The E. racemosum hydrocauli in the reproductive period may be compared to these mature colonies, whilst the young gorgonian colonies can be viewed similar to the short, dense colonies of the hydrozoan. In our view, it is important to stress again that it is not the prey per polyp that is favorable in the reproductive period (see Fig. 6), but the change in morphology of the hydrocaulus that optimizes the feeding surface of the patch and lets the hydrocauli accumulate essential energy stores that will be transferred to their offspring.

More importantly, as the patch structure changes to larger colonies, the trophic impact increases. This key point suggests that larger colonies have a more prominent role in benthic-pelagic coupling and in biogeochemical cycles than smaller ones. A 3-fold impact on the plankton community is not negligible, and the retention of carbon and nutrient cycling (by digestion, egesting and excretion) are more impor- tant as the hydrocauli grow and the capture surface increases as well. Compared with long-lived species, the present results demonstrate that larger colonies of e.g. gorgonians, alcyonarians and hard corals have a greater impact on benthic-pelagic processes and carbon retention than a denser patch of smaller colonies. In hydrozoans, carbon retention passes from ephemeral, fast-growing plankton to more stable structures (the hydrocaulus). In long-lived species, seston passes from the water column to the structural parts of animals which can retain carbon for decades or centuries.

There is increasing interest in the real impact of larger structures (land forests, kelp forests, seagrasses, animal forests) in carbon retention as they become older and more mature. Larger colonies will have a greater impact than non-mature populations on benthic-pelagic coupling and biogeochemical cycles and processes. In gorgonians, large colonies have a larger trophic impact and energy output (in terms of gonadal output, growth, and carbon retention in the structures) (Coma et al. 1998, Lasker et al. 1998, Rossi et al. 2008, Rossi \& Gili 2009), but the possibility of comparing young and old populations has never been followed up. In the present study, we suggest that, taking into account the precise population dynamics of fast-growing species (which have similar growing structures compared to long-lived ones) and their trophic impact, we can make an acceptable extrapolation to the long-lived clonal animals, connecting these results to better understand the real impact of the animal forest in biogeochemical cycles.

\section{CONCLUSIONS}

The population dynamics of fast-growing benthic suspension feeders reproduce, in a short time scale, the dynamics of long-lived species in which oscillations between size structure characterized by abundance of alternatively small or large colonies are supposed to occur over decades (Linares et al. 2008, Bramanti et al. 2009).

The strategy of suspension feeders to change patch structure over the annual cycle can be summarized in 3 points: (1) reproduction time is in spring, when the increase in feeding surface/hydrocaulus is highest; (2) a fast increase in height occurs within a few weeks, to avoid the trophic shadow of fleshy algae and compete better for food; and (3) lipids are accumulated in the hydrocaulus during the reproductive period. An optimal demographic structure for 
patches seems to enable the population to catch more prey and to accumulate energy for transfer to their offspring. The present study can be considered an interesting approach to the impact of animal forests on carbon retention and cycling using a fast-growing species as a model.

Acknowledgements. We are very grateful to J. Pascual for the water temperature data set. Carbon/nitrogen analysis was provided by the Scientist Technical Service (University of Barcelona) with the assistance of I. Casals and P. Fernandez. Support for this work was provided by a FPI fellowship from the 'Ministerio de Educación y Ciencia' and a Ramón y Cajal Contract (RyC-2007-01327) to S.R., by a CICYT grant and by the MAST-III-ELOISE European Union METRO MED Project. L.B. was supported by a Marie Curie IntraEuropean Fellowship within the 7th European Community Framework Programme (Project No. 221072).

\section{LITERATURE CITED}

Adjeroud M, Pratchett MS, Kospartov MC, Lejeusne C, Penin L (2007) Small-scale variability in the size structure of scleractinian corals around Moorea, French Polynesia: patterns across depths and locations. Hydrobiologia 589:117-126

Arrigoni M, Manfredi P, Panigada S, Bramanti L, Santangelo G (2011) Life-history tables of the Mediterranean fin whale from stranding data. Mar Ecol 32:1-9

Babcock RC (1991) Comparative demography of three species of scleractinian corals using age- and size-dependent classifications. Ecol Monogr 61:225-244

Bak RPM, Meesters EH (1998) Coral population structure: the hidden information of colony size-frequency distributions. Mar Ecol Prog Ser 162:301-306

Ballesteros E (1992) Els vegetals i la zonació litoral: espècies, comunitats i factors que influeixen en la seva distribució. Institut d'Estudis Catalans, Barcelona, p 351-366

> Barangé M (1988) Prey selection and capture strategies of the benthic hydroid Eudendrium racemosum. Mar Ecol Prog Ser 47:83-88

> Barangé M, Gili JM (1988) Feeding cycles and prey capture in Eudendrium racemosum (Cavolini, 1785). J Exp Mar Biol Ecol 115:281-293

Barangé M, Zabala M, Riera T, Gili JM (1989) A general approach to the in situ budget of Eudendrium racemosum (Cnidaria, Hydrozoa) in the western Mediterranean. Sci Mar 53:423-427

> Barnes H, Blackstock J (1973) Estimation of lipids in marine animals and tissue: detailed investigation of the sulphophosphovanillin method for 'total' lipids. J Exp Mar Biol Ecol 12:103-118

Bavestrello G, Puce S, Cerrano C, Zocchi E, Boero N (2006) The problem of seasonality of benthic hydroids in temperate waters. Chem Ecol 22(Supp 1):197-205

Beers JR (1966) Studies on the chemical composition of the major zooplankton groups in the Sargasso Sea off Bermuda. Limnol Oceanogr 11:520-528

Biswas AK, Biswas MR (1979) Handbook of environmental data and ecological parameters, Vol 6. Environmental sciences and applications. Pergamon, Oxford
Blackwood J, Hastings A, Mumby P (2010) The effect of fishing on hysteresis in Caribbean coral reefs. Theor Ecol 5: 105-114

Boero F, Fresi E (1986) Zonation and evolution of a rocky bottom hydroid community. PSZN I: Mar Ecol 7:123-150

Boero F, Balduzzi A, Bavestrello G, Caffa B, Cattaneo-Vietti R (1986) Population dynamics of Eudendrium glomeratum (Cnidaria, Anthomedusae) on Portofino promontory (Ligurian Sea). Mar Biol 92:81-85

> Bramanti L, Santangelo G, Iannelli M (2009) Mathematical modelling for conservation and management of gorgonian corals: Young and olds, could they coexist? Ecol Model 220:2851-2856

> Bryan PJ, McClintock JB, Baker BJ (1998) Population biology and antipredator defenses of the shallow-water Antarctic nudibranch Tritoniella belli. Mar Biol 132: 259-265

Buss LW (1979) Habitat selection, directional growth and spatial refuges: why colonial animals have more hiding places. In: Larwood G, Rosen BR (eds) Biology and systematics of colonial organisms. Systematics Assoc Spec Vol 11. Academic Press, London, p 459-497

> Calder DR (1990) Seasonal cycles of activity and inactivity in some hydroids from Virginia and South Carolina, USA. Can J Zool 68:442-450

Calder DR, Maÿal EM (1998) Dry season distribution of hydroids in a small tropical estuary, Pernambuco, Brazil. Zool Verh 323:69-78

Coma R, Llobet I, Zabala M, Gili JM, Hughes RG (1992) The population dynamics of Halecium petrosum and Halecium pusillum (Hydrozoa, Cnidaria), epiphytes of Halimeda tuna in the northwestern Mediterranean. Sci Mar 56:161-169

Coma R, Gili JM, Zabala M, Riera T (1994) Feeding and prey capture cycles in the aposymbiontic gorgonian Paramuricea clavata. Mar Ecol Prog Ser 115:257-270

> Coma R, Lobet I, Gili JM, Zabala M (1996) Quantification of sexual reproduction in the marine benthic hydroid Campanularia everta. Mar Biol 125:365-373

Coma R, Ribes M, Gili JM, Zabala M (1998) An energetic approach to the study of life-history traits of two modular colonial benthic invertebrates. Mar Ecol Prog Ser 162: 89-103

Coma R, Ribes M, Gili JM, Zabala M (2000) Seasonality in coastal benthic ecosystems. Trends Ecol Evol 15:448-453

> Di Camillo CG, Betti F, Bo M, Martinelli M, Puce S, Vasapollo C, Bavestrello G (2012) Population dynamics of Eudendrium racemosum (Cnidaria, Hydrozoa) from the North Adriatic Sea. Mar Biol 159:1593-1609

- Enquist BJ, Brown JH, West GB (1998) Allometric scaling of plant energetics and population density. Nature 395: 163-165

Fujiwara M, Caswell H (2001) Demography of endangered North Atlantic right whale. Nature 414:537-541

> Garrabou J, Ballesteros E, Zabala M (2002) Structure and dynamics of north-western Mediterranean rocky benthic communities along a depth gradient. Estuar Coast Shelf Sci 55:493-508

Gili JM, Coma R (1998) Benthic suspension feeders: their paramount role in littoral marine food webs. Trends Ecol Evol 13:316-321

Gili JM, Hughes RG (1995) The ecology of marine benthic hydroids. Oceanogr Mar Biol Annu Rev 33:351-426

Gili JM, Ros J (1985) Study and cartography of the benthic communities of the Medes Islands (NE Spain). PSZN I: 
Mar Ecol 6:219-238

Gili JM, Hughes RG, Alvà V (1996) A quantitative study of feeding by the hydroid Tubularia larynx Ellis and Solander, 1786. Sci Mar 60:43-54

Gili JM, Duró A, García-Valero J, Gasol JM, Rossi S (2008) Herbivorism in small carnivores: benthic hydroids as an example. J Mar Biol Assoc UK 88:1541-1546

> Gori A, Linares C, Rossi S, Coma R, Gili JM (2007) Spatial variability in reproductive cycles of the gorgonians Paramuricea clavata and Eunicella singularis in the western Mediterranean. Mar Biol 151:1571-1584

- Gori A, Rossi S, Linares C, Berganzo E, Orejas C, Dale MRT, Gili JM (2011) Size and spatial structure in deep vs shallow populations of the Mediterranean gorgonian Eunicella singularis (Cap de Creus, northwestern Mediterranean Sea). Mar Biol 158:1721-1732

> Grémare A, Amouroux JM, Charles F, Dinet A and others (1997) Temporal changes in the biochemical composition and nutritional value of the particulate organic matter available to surface deposit-feeders: a two year study. Mar Ecol Prog Ser 150:195-206

> Hall DJ, Cooper WE, Werner EE (1970) An experimental approach to the production dynamics and structure of freshwater animal communities. Limnol Oceanogr 15: 839-928

> Helmuth B, Sebens KP (1993) The influence of colony morphology and orientation to flow on particle capture by the scleractinian coral Agaricia agaricites (Linnaeus). J Exp Mar Biol Ecol 165:251-278

> Heppell SS, Crowder LB, Crouse DT (1996) Models to evaluate headstarting as a management tool for long-lived turtles. Ecol Appl 6:556-565

> Hughes TP (1989) Community structure and diversity of coral reefs: the role of history. Ecology 70:275-279

$>$ Hughes TP, Jackson JBC (1985) Population dynamics and life histories of foliaceous corals. Ecol Monogr 55: 141-166

> Hughes TP, Baird AH, Bellwood DR, Card M and others (2003) Climate change, human impacts, and the resilience of coral reefs. Science 301:929-933

> Hunter T (1989) Suspension feeding in oscillating flow: the effects of colony morphology and flow regime on plankton capture by the hydroid Obelia longissima. Biol Bull (Woods Hole) 176:41-49

> Jackson JBC (1977) Competition on marine hard substrata: the adaptative significance of solitary and colonial strategies. Am Nat 111:743-767

> Kim K, Lasker HR (1997) Flow-mediated resource competition in the suspension feeding gorgonian Plexaura homomalla (Esper). J Exp Mar Biol Ecol 215:49-64

Komsta L, Novomestky F (2011) Moments: moments, cumulants, skewness, kurtosis and related tests. R package Version 0.12. Available at: http://CRAN.R-project.org/ package $=$ moments

> Lasker HR, Kim K, Coffroth MA (1998) Production, settlement, and survival of plexaurid gorgonian recruits. Mar Ecol Prog Ser 162:111-123

> Lewin R (1986) Supply-side ecology. Science 234:25-27

Linares C, Coma R, Garrabou J, Díaz D, Zabala M (2008) Size distribution, density and disturbance in two Mediterranean gorgonians: Paramuricea clavata and Eunicella singularis. J Appl Ecol 45:688-699

Linares C, Bianchimani O, Torrents O, Marschal C, Drap P, Garrabou J (2010) Marine Protected Areas and the conservation of long-lived marine invertebrates: the Medi- terranean red coral. Mar Ecol Prog Ser 402:69-79

> Llobet I, Gili JM, Hughes RG (1991) Horizontal, vertical and seasonal distributions of epiphytic hydrozoa on the alga Halimeda tuna in the northwestern Mediterranean Sea. Mar Biol 110:151-159

MacLeod P, Valiela I (1975) The effect of density and mutual interference by a predator: a laboratory study of predation by the nudibranch Coryphella rufibranchialis on the hydroid Tubularia larynx. Hydrobiologia 47:339-346

Margalef R (1974) Ecología. Omega, Barcelona

- Martin R (2003) Management of nematocysts in the alimentary tract and in cnidosacs of the aeolid nudibranch gastropod Cratena peregrina. Mar Biol 143:533-541

Martin R, Walther P (2003) Protective mechanisms against the action of nematocysts in the epidermis of Cratena peregrina and Flabellina affinis (Gastropoda, Nudibranchia). Zoomorphology 122:25-35

McClanahan TR, Muthiga NA (1988) Changes in Kenyan coral reef community structure and function due to exploitation. Hydrobiologia 166:269-276

McFadden CS (1986) Colony fission increases particle capture rates of a soft coral: advantages of being a small colony. J Exp Mar Biol Ecol 103:1-20

McMahon T (1973) Size and shape in biology. Science 179: 1201-1204

Miyanishi K, Hoy AR, Cavers PB (1979) A generalized law of self-thinning in plant populations (self-thinning in plant populations). J Theor Biol 78:439-442

Muller-Landau HC, Condit RS, Harm KE, Marks CO and others (2006) Comparing tropical forest tree size distributions with the predictions of metabolic ecology and equilibrium models. Ecol Lett 9:589-602

> Oliveira OMP, Marques AC, Migotto AE (2000) Morphometric patterns of two fouling Eudendrium spp. (Hydrozoa, Anthomedusae, Eudendriidae) from Sao Sebastiao (SP, SE Brazil). Braz Arch Biol Technol 43:519-526

> Paffenhofer GA (1968) Nahrungsaufnahme, Stoffumsatz und Energiehaushalt des marinen Hydropolypen Clava multicornis. Helgol Wiss Meeresunters 18:1-44

Paine RT (1994) Marine rocky shores and community ecology: an experimentalist's perspective. In: Kinne O (ed) Excellence in ecology, Vol 4. Ecology Institute, Oldendorf/Luhe, p 95-105

Patterson MR (1992) A mass transfer explanation of metabolic scaling relations in some aquatic invertebrates and algae. Science 255:1421-1423

Pulliam HR (1996) Sources and sinks: empirical evidence and population consequences. In: Rhodes OE, Chesse RK, Smith MH (eds) Population dynamics in space and time. University of Chicago Press, Chicago, IL, p 45-69

> Ribera d'Alcalá M, Conversano F, Corato F, Licandro P and others (2004) Seasonal patterns in plankton communities in a pluriannual time series at a coastal Mediterranean site (Gulf of Naples): an attempt to discern recurrences and trends. Sci Mar 68:65-83

> Rossi S, Gili JM (2005) Temporal variation and composition of near-bottom seston features in a Mediterranean coastal area. Estuar Coast Shelf Sci 65:385-395

Rossi S, Gili JM (2009) Reproductive features and gonadal development cycle of the soft bottom-gravel gorgonian Leptogorgia sarmentosa (Esper, 1791) in the NW Mediterranean Sea. Invertebr Reprod Dev 53:175-190

Rossi S, Tsounis G (2007) Temporal and spatial variation in protein, carbohydrate, and lipid levels in Corallium rubrum (Anthozoa, Octocorallia). Mar Biol 152:429-439 
Rossi S, Grémare A, Gili JM, Amouroux JM, Jordana E, Vétion G (2003) Biochemical characteristics of settling particulate organic matter at two north-western Mediterranean sites: a seasonal comparison. Estuar Coast Shelf Sci 58:423-434

Rossi S, Ribes M, Coma R, Gili JM (2004) Temporal variability in zooplankton prey capture rate of the passive suspension feeder Leptogorgia sarmentosa (Cnidaria: Octocorallia), a case study. Mar Biol 144:89-99

Rossi S, Gili JM, Coma R, Linares C, Gori A, Vert N (2006) Seasonal cycles of protein, carbohydrate and lipid concentrations in Paramuricea clavata: (Anthozoa, Octocorallia): evidence for summer-autumn feeding constraints. Mar Biol 149:643-651

Rossi S, Tsounis G, Orejas C, Padrón T and others (2008) Survey of deep-dwelling red coral (Corallium rubrum) populations at Cap de Creus (NW Mediterranean). Mar Biol 154:533-545

Rossi S, Gili JM, Garrofé X (2011) Net negative growth detected in a population of Leptogorgia sarmentosa: quantifying the biomass loss in a benthic soft bottomgravel gorgonian. Mar Biol 158:1631-1643

Santangelo G, Bramanti L (2006) Ecology through time: an overview. Riv Biol / Biol Forum 99:395-424

Santangelo G, Maggi E, Bramanti L, Bongiorni L (2004) Demography of the over-exploited Mediterranean red coral (Corallium rubrum L., 1758). Sci Mar 67:199-204

Santangelo G, Bramanti L, Iannelli M (2007) Population dynamics and conservation biology of the over-exploited

Editorial responsibility: Peter Edmunds, Northridge, California, USA
Mediterranean red coral. J Theor Biol 244:416-423

Sebens KP (1982) Competition for space: growth rate, reproductive output, and escape in size. Am Nat 120:189-197

Sebens KP, Johnson AS (1991) Effects of water movement on prey capture and distribution of reef corals. Hydrobiologia 226:91-101

Sebens KP, Koehl MAR (1984) Predation on zooplankton by benthic anthozoans Alcyonum siderium (Alcyonacea) and Metridium senile (Actiniaria) in the New England subtidal. Mar Biol 81:255-271

Sommer C (1992) Larval biology and dispersal of Eudendrium racemosum (Hydrozoa, Eudendriidae). Sci Mar 56: 205-211

> Sousa WP (1979) Disturbance in marine intertidal boulder fields: the nonequilibrium maintenance of species diversity. Ecology 60:1225-1239

Vermeij MJA, Bak RPM (2000) Inferring demographic processes from population size structure in corals. In: Proc 9th Int Coral Reef Symp, Bali 1:589-594

Vogel S (1981) Life in moving fluids. Princeton University Press, Princeton, NJ

- White J (1981) The allometric interpretation of the selfthinning rule. J Theor Biol 89:475-500

Yoda K, Kira T, Ogawa H, Hozumi K (1963) Self-thinning in overcrowded pure stands under cultivated and natural conditions. Intraspecific competition among higher plants. J Biol Osaka City Univ 14:107-129

Zar JH (1996) Biostatistical analysis, 3rd edn. Prentice Hall International Editions, Englewood Cliffs, NJ

Submitted: December 16, 2011; Accepted: May 26, 2011

Proofs received from author(s): October 15, 2012 